\title{
Striking art reflects his struggle
}

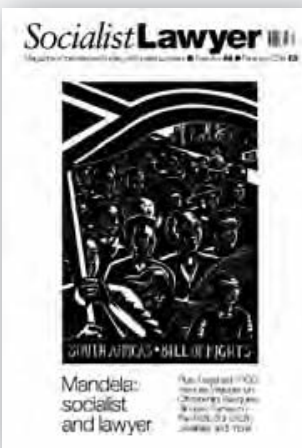

Coverillustration: South Africa's Bill of Rights (1998) by Norman Kaplan (see pages 22-23). This print was chosen in open competition as the front piece and cover of a boxed set of prints commissioned by Amnesty International South Africa to celebrate South Africa's progressive Bill of Rights. The prints were later engraved on large glass panels mounted in the new Constitutional Court building in Johannesburg.
In this issue of Socialist Lawyer we pay tribute to Nelson Mandela, remembering his radical roots, his work as a lawyer, and featuring some of the striking art inspired by the anti-apartheid struggle. As the author Steven Walker explores in his article, these early radical influences in Mandela's political education and formation were often air-brushed out of much of the coverage that surrounded his passing. They are nonetheless worth recalling.

We are grateful to be able to feature the art work of South African printmaker Norman Kaplan who captures in his prints some of the strong sentiments evoked by South Africa's recent history. The image featured on the cover of this issue pays homage to South Africa's progressive Bill of Rights that was adopted as the apartheid era was brought to an end. It is a print which is mounted on display in the Constitutional Court building in Johannesburg.

The 6th January 2014 was a promising day in the campaign to save legal aid. The half-day of action organised by the Criminal Bar Association (CBA) was the first time lawyers had taken steps to, in effect, withdraw their labour. It was a reflection of how seriously the proposed further round of cuts to legal aid threaten the concept of access to justice in England and Wales.

The Justice Alliance continues to coordinate and lead the campaign to save legal aid. It organised a well-attended demonstration outside Westminster Magistrates' Court on 6th January 2014 to coincide with the CBA's half-day of action. Despite the predictable responses and caricatures that emerged from certain sections of the right-wing press, the events of 6 th January 2014 attracted a great deal of positive publicity. The message is resonating that the campaign is about protecting the most vulnerable in society and ensuring that access to justice is not solely the preserve of the wealthy.

The campaign to save legal aid has seen a great deal of unity across the profession from solicitors and barristers. A further day of action by lawyers is expected to take place on 7th March 2014. The Justice Alliance has also launched a petition at www.change.org calling on David Cameron to halt the proposals set out in the Government's paper Transforming Legal Aid. At the time of writing the petition had gathered some 15,642 signatures. Matters surrounding the ongoing campaign are explored in articles in this issue. Siobhán Lloyd summarises the Haldane Society's response to the
Low Commission's consultation. Dr Daniel Newman from the University of Cardiff sets out some of the findings of a year long research study into access to justice, while Connor Johnston of Young Legal Aid Lawyers considers some of the debates that lie ahead for the campaign.

It is worth recalling that the 2013 Liberal Democrat party conference held in Glasgow voted to oppose further cuts to legal aid until it can be demonstrated that there will be 'no adverse effect upon access to justice'. This is something of which the Deputy Prime Minister Nick Clegg and all Liberal Democrat MPs should be persistently reminded.

As recent events in the UK have illustrated, climate change and the environment are issues that remain to the fore. Richard Harvey looks back at the events and legal proceedings that unfolded in Russia and beyond as 30 Greenpeace activists were imprisoned for taking a stand in the Arctic. It is a pleasure to be able to feature in this issue the poetry of Brian Turner, New Zealand's former Poet Laureate. Brian Turner's poems reflect his love for the Central Otago region of New Zealand where he lives, as well as the environment. He is known in his home country for his environmental activism. Featured in these pages are three poems that appear in Turner's new book Elemental.

There is considered analysis in this issue by Frances Webber in respect of questions surrounding citizenship. There is also an overview of some of the recent concerns that have arisen in respect of the Independent Police Complaints Commission (IPCC). A recent report on the BBC's Newsnight outlined how plans are being formulated by the Government to significantly increase staff numbers at the IPCC. As Daniela Tringale argues, there is a strong case for more farreaching reforms to be made to the IPCC.

With the football World Cup just over three months away, we follow up on the features on Brazil in Socialist Lawyer 65 with a report on disturbing events in the remote north-west state of Rondônia.

There are numerous upcoming Haldane Society events in 2014, including the regular annual talk known as In Conversation on 14th May 2014 which is organised together with the Institute of Employment Rights. A forum for debate, discussion and action, the Haldane Society continues to be as active as ever.

Tim Potter (socialistlawyer@haldane.org) 